
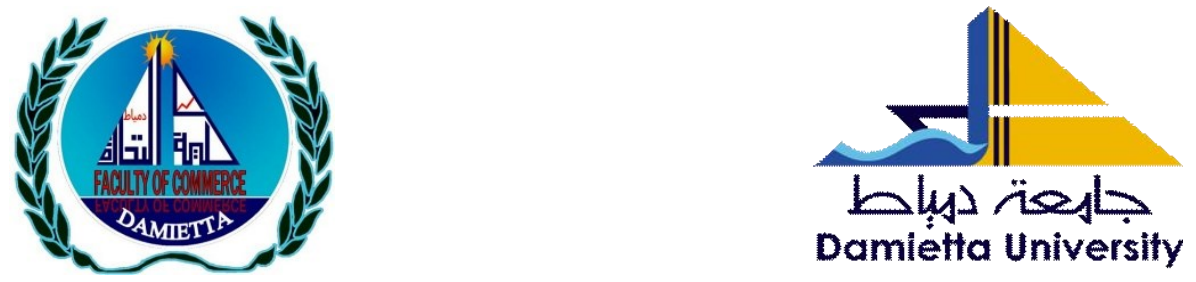

\title{
Integrating student engagement with the DeLone \& McLean model to assess the effectiveness of Online Learning System during COVID-19 pandemic
}

Prepared by

Dr. Reham Shawky Ebrahim

Lecturer of Business Administration

Faculty of Commerce - Tanta University

reham.ibrahim@commerce.tanta.edu.eg
Prof. Dr. Waleed Afify

Professor of Mathematics and Statistics Faculty of commerce, Kafrelsheikh University waleedafify@yahoo.com

\section{Dr Reda Shaker Abdelkareem}

Lecturer of Business Administration

Faculty of Commerce - Kafrelsheikh University

reda.abdelkareem@com.kfs.edu.eg

\section{Scientific Journal for Financial and Commercial Studies and} Researches (SJFCSR)

Faculty of Commerce - Damietta University

Vol.2, No.1, Part 1., Jan. 2021

\section{APA Citation:}

Ebrahim, R. S.; Afify, W. and Abdelkareem, R. S. (2021). Integrating student engagement with the DeLone \& McLean model to assess the effectiveness of Online Learning System during COVID-19 pandemic. Scientific Journal for Financial and Commercial Studies and Researches (SJFCSR), Vol.2 (1) Part1. pp. 384- 424.

Website: https://cfdi.journals.ekb.eg/ 


\begin{abstract}
The Coronavirus pandemic has created significant challenges for higher education institutions and rushed them toward the utilization of IT resources to practice online learning as a replacement of the face-to-face classrooms. This study aims to assess the effectiveness of the online learning system (OLS) in driving student engagement and generating positive performance impact during the Coronavirus outbreak. A conceptual model is proposed by adopting the D\&M model to examine the impact of the OLS overall quality dimensions (system quality, information quality, and service quality) on student's performance impact and to study the mediating effect of actual use, student satisfaction, and student engagement on this relationship. By depending on a sample of 781stuents at both ungraduated and postgraduate levels enrolled at public universities in Egypt, using a self-administrated online survey to collect the data and SEM-PLS to analyze the data. The results indicate the significance of OLS quality dimensions direct effect on actual use, student satisfaction, student engagement and performance impact. Also, student engagement has the highest direct effect on performance impact and indirectly it enhances the relationship between overall quality dimensions and performance impact. These findings suggest several theoretical and managerial implications which specifically highlight the importance of overall quality and student engagement as determinants of OLS effectiveness.
\end{abstract}

Keywords: Online Learning system, student engagement, performance impact, D\&M model 


\section{Introduction}

On 20 March 2020 universities were closed in response to the COVID-19 pandemic and more than 890 million students in 114 counties were affected. The closure raised a significant number of challenges faced by higher education institutions in different areas including financial risks and funds, recruitment of students and admissions for the new academic year, housing and accommodation, quality standards of delivered service, assessment and evaluation of current students and support of student mental health issues (Araújo et al., 2020; Hubble \& Bolton, 2020). Universities have been forced to consider larger-scale preventative measures to keep their students, staff and academic members safe and avoid infections from being materialized on their campus. Moreover, educational institutions are less prepared today to face the long-term impact of Coronavirus and help students during the outbreak. Consequently, faculties are rushed to the online learning; converting curriculum to the online environment using a mindful of technology and websites (Crawford et al., 2020). The online learning environment is overcoming the time and place boundaries and remove the burden of physical attendance comparing to face-to-face (Aldholay et al., 2018; Bond et al., 2020); therefore, taking the advantage of technology in higher education is now a must than ever before.

Online learning (OL) is used interchangeably with distant learning or e-learning, it refers to the digitalization of the education system, that is using internet and information technology to deliver the service (Isaac et al., 2019). Without exceptions, the growth of $\mathrm{OL}$ is among public and private, for-profits and not-for-profit institutions, and online teaching is now the new routine for students. Inherently, information technology is playing a crucial role in higher education given that it has the potential to make teaching and learning processes more intensive, increase its flexibility and convenience and enhances its quality (Isaac et al., 2019). The use of 
digital technology in higher education increases digital literacy and develop student's ICT, interdisciplinary and collaborative skills (Bond et al., 2020). Learners are encouraged to discover different self-perspectives through remote incorporation in activities and to improve their self-regulation and self-efficacy.

Despite the technological innovation and wide broadband accessibility, several challenges are presented such as social inequality and inaccessibility of learners to such type of education. However, in the short term, colleges and universities must continue to solve these profound complexities (Araújo et al., 2020). At this transitionary period, the main response is the necessity to digitalize the educational system without compromising the quality of the academic service provided and meeting the standards of the curriculum.

It is important to assess the effectiveness of the provided OLS during the Coronavirus outbreak. By revising the literature, there are plenty of studies on online learning, the majority of these studies are focusing on investigating the factors affecting the users' attitudes (satisfaction) toward the system (Alves \& Raposo, 2007; Ijaz et al., 2011; Liaw et al., 2007; Montesdioca \& Maçada, 2015; Nadiri et al., 2009; Yilmaz, 2017a), intentions (Cheng, 2012) and actual use (Lin, 2007; Lwoga, 2014a). Another group of studies extend the effects of the actual use of OLS and evaluate the IT usage on net benefits at both the organizational level and individual level. Among which is the study of (Chen, 2010) that tests the transfer of acquired skills from OLS to the work context and investigates the transmission of OLS effectiveness on job outcomes. Whereas, at the individual level, the studies focusing on the evaluation of OLS effectiveness and benefits examine the effects of system use on student's academic performance exhibited by grades (Islam, 2013; Ortiz et al., 2004). The advancement of new technologies is improving the efficiency and effectiveness of individual and organizational performance impact. Nevertheless, a handful of studies broadly described 
performance to embrace other competencies such as knowledge acquisition, decision and communication qualities (Isaac et al., 2019), quick task accomplishment, improvements in job performance, enhancement of job effectiveness and quality of work, elimination of error, control over work (Daud, 2011).

The effectiveness of OL and its ability to promote better learning requires student engagement. Active learners who are intrinsically motivated to interact with the system and getting deeply involved in the learning environment and its activities are most likely to get benefited from its intended outcomes (Bond et al., 2020; Jung \& Lee, 2018). IT resources provide multiple ways to digitalize education that can be categorized into traditional education technology including online discussion boards, general websites, Moodle-based teaching platforms and other designed college software, and social media applications on different social network sites such as Facebook and Twitter (Rueda et al., 2017).

The raising importance of the concept of engagement across different disciplines led to the development of a growing number of studies at the last decade which attempt to explore the predictors and outcomes of student engagement with OL technologies. By mapping the extant literature of student engagement with OL technologies, students initiative to engage with a system depends on actual usage and attitude (Francescucci \& Rohani, 2019; Rueda et al., 2017), learner characteristics (Hew \& Cheung, 2014), self-efficacy and other intrinsic motivations (Tseng \& Tsai, 2010); while, the great focus is on the positive impact of student engagement on academic achievement and course grade (Cronin et al., 2000; Francescucci \& Rohani, 2019). Also, inconsistencies exist among these studies in terms of the aspects depicting engagement with OL due to the lack of validated scale, and its definition. Most researches are using engagement interchangeably with usage and measure it with related activities such as number of visits and length of time spent logged in (Dunn \& Kennedy, 2019). 
This research attempts to associate the use of OLS in higher education during Coronavirus outbreak with the learning outcomes, determine its effectiveness by student engagement, and compare different weighted effects of predictors on performance. To fulfill these objectives, a conceptual model is developed following the D\&M IS success model to examine the impact of extrinsic factors related to the overall quality of OLS on the system usage and its consecutive outcomes; while considering the mediating role of student engagement. The D\&M is one of the most widely cited IS model that depends on the qualities of an information system to measure its effectiveness. Besides, the model is well researched to predict the behaviour of an individual in different settings for example electronic commerce (Hsu et al., 2014; Liang \& Chen, 2009), mobile banking (Tam \& Oliveira, 2016, 2017). It is believed that using the D\&M model in educational settings will contribute to the assessment of online learning success, unlike other theories for technology acceptance and use, such as the TAM. Since the D\&M IS model goes beyond user behavior and provides the theoretical support to the relationship between OL and outcomes; net benefits (organizational and individual impact) (Islam, 2013). Hence, it is reasonable to expect that student performance and engagement with the online learning system will depend on their perceptions of the IS qualities.

Therefore, this study fills the gap in the literature and makes three contributions. First, it extends and unlimited the impact of OLS usage on grades and focuses on performance impact broadly based on resources (cost, time, and effort) savings, knowledge acquisition, skills development, elimination of errors, performance improvement, enhancement of effectiveness and creation of innovative ideas. Second, it assesses the effectiveness of OL by student engagement rather than focusing on academic achievement solely. Third, it uncovers the mediating role of student engagement, measured by a validated scale developed with respect to online learning, in the relationship between OL system quality aspects and its benefits. 


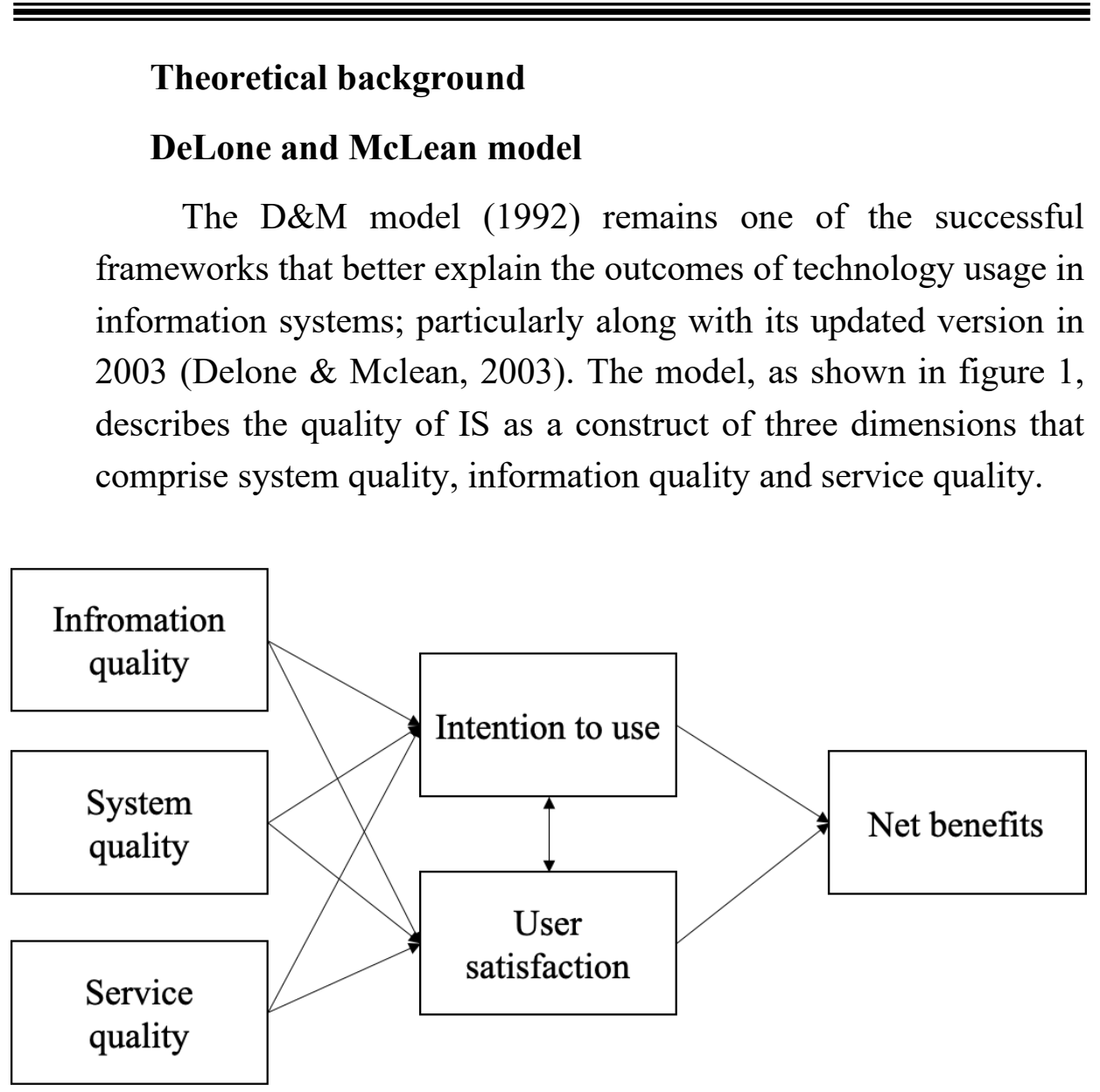

Figure 1: The updated DeLone and McLean IS success model

System quality refers to the enjoyable use of the system generated from the ease of use, connect and learn the system (Isaac et al., 2017). Information quality described as the accuracy, timeliness, completeness, relevance, consistency of the information provided by the online system (Halonen et al., 2009). Service quality entails the responsiveness, attractiveness, organizing, empathy and appealing interface provided by the online IS (Delone \& Mclean, 2003; H. F. Lin, 2007a). According to Tam and Oliveira (2016), the 
user attitude influences the impact of online IS on performance. Thus, the general theory of IS postulates that the correspondence between system quality, information quality and service quality will have a positive impact on performance with respect to the end user satisfaction and intention to reuse the system (Iivari, 2005)

However, the empirical examination of the theory provides mixed results. While, Iivari (2005) found that system quality and information quality have a significant positive impact on user satisfaction and have no effect on system use, Jagannathan et al., (2018) found system quality has no impact on user satisfaction; whereas, information quality significantly affects user satisfaction. According to Lin (2007), the impact of system, service and information quality on actual use of OLS depends on the user satisfaction and behavioral intention to use the system. Lwoga (2014b) has adopted the model to examine students' antecedents to use web-based learning system; however, the results unexpectedly confirmed no relationship between service quality and information quality from one side and user satisfaction from the other side. However, Chen (2010) and Cheng (2012) indicated the positive impact of system quality, information quality and service quality on user satisfaction, learners' intention to use an e-learning system and perceived usefulness.

Several studies have used the D\&M model as a theoretical foundation; however, the importance of such IS model to be adapted in the OLS increases during the current COVID-19 pandemic. The need to provide an effective learning environment that breaks space limitations and provide high-quality distance learning during the current pandemic repeat shine to the D\&M model. Indeed, few studies investigated the model in learning success systems (e.g. Cheok \& Wong, 2015; Isaac et al., 2017; Lin, 2007), however, this 
study is another empirical examination for such important theory during crisis time that impose on all parts whether universities or students to use the OL system. Furthermore, it is worthwhile to investigates the model in a new context to provide solid empirical evidence to the contradictory results.

\section{Engagement in higher education}

Engagement is one of the most cited predictors for educational success; therefore, many endeavors have been done to examine how best to foster engagement in higher education. Hence, promoting engagement among learners has been emphasized as one of the main goals by most universities; particularly with the advent of digital technology that drove the growth of e-learning and distance learning (Kong \& Song, 2015). Engagement is defined as "the amount of physical and psychological energy that the student devotes to the academic experience" (Astin, 1984, p.297). Engagement in higher education is described as student investment of time, commitment and resources towards learning activities (Krause \& Coates, 2008). However, Trowler (2010) extended the engagement definition to include the investment of time, commitment and relevant resources for both students and their universities to enhance students' experience and optimize learning outcomes and develop students' performance that increases institution's reputation. However, due to the growing trend of learners centered activities (Kong \& Song, 2015), more researches even this research focus on student engagement. The comprehensive definition of engagement from the student point of view converges to cover three important interrelated aspects cognitive, behavioral, and affective or emotional (Handelsman et al., 2005). The cognitive aspect refers to the psychological investment that student advocates for academic work, feelings of control and educational goals (Lawson \& Lawson, 2013). 
While, behavioral aspect is objectively observed that entails participation, attendance and completion of an assignment, the affective or emotional aspect is more subjective related to student perceptions of learning activities and support (Maguire et al., 2017). Other scholars (e.g., Appleton et al., 2006; Fredricks et al., 2004) have added one more aspect for student engagement to be four interrelated distinct aspects: academic, behavioral, cognitive and emotional. However, the three-component model for student engagement is the most widely accepted model (Ding et al., 2017).

Consequently, for the current COVID-19 pandemic, student engagement concept will be restricted to distance learning away from teacher-student classroom interaction. Therefore, behavioral engagement could be in the form of online participation or interaction with teacher or peers' posts. According to (Goggins \& Xing, 2016), the amount of discussion posts is an indicator for behavioral engagement. Cognitive engagement in OL activities "involves the use of higher-order thinking skills (e.g., analyzing, critiquing, and reasoning) and self-regulated learning strategies, in reading and composing posts in online discussions" (Ding et al., 2017 p.128). Emotional engagement in OL system entails students' enjoyment in online discussions, well presented and visualized materials and the social interactions with their peers and teachers (Ding et al., 2017).

To emphasize, many benefits for student engagement have been drawn by many scholars. For instance, there is a positive significant impact for engagement in higher education on student retention (Kuh et al., 2008); academic performance (Pascarella et al., 2010); high grades and learners' satisfaction (Carini et al., 2006; Chen et al., 2008); skills development (Quaye \& Harper, 2014). Despite the fact of empirically confirmed benefits of the student 
engagement and the massive stream of the studies that establish practices that enhance the concept in higher education (Kuh \& Schneider, 2008b) the student engagement concept is left relatively weakly theorized (Kahn, 2014). According to Kuh and Schneider (2008a), the active collaboration between students, studentsfaculties and supportive environment enhance and contribute to student engagement but such discourse needs to be profoundly theorized. Furthermore, (Carini et al., 2006), have relied the variations of students' learning outcomes to the divergent of students' engagement in education activities.

Given the importance of the lack of attention to the theoretical foundation of student engagement in higher education (Kahn, 2014); and the number of researches that confirm the benefits of such an important concept and degree of variation between different learners, it is worth scrutinizing the application of further theoretical viewpoints. In looking to add to the theoretical foundation for student engagement in this paper, we initially looking to the D\&M model and how perceived student overall quality affects the level of student engagement that consequently affects student performance.

\section{Performance impact}

Enhancing performance is the ultimate goal for most of the educational activities (e.g. Ding et al., 2017; Goggins \& Xing, 2016; Isaac et al., 2017; Krause \& Coates, 2008; Lin, 2007b; Pascarella et al., 2010; Tam \& Oliveira, 2016). According to Picciano (2002), student performance might be measured in various ways and its definition translates the development of students' knowledge, skills, grades, and successful course completion. Different ways used universally to measure students' performance, all of it aims to evaluate the achievement of course objectives (Francescucci \& 
Rohani, 2019). Performance impact can be seen as the extent to which OLS use helps in improving students' performance, reinforcing students' efficiency, completing tasks effectively, exerting task control and eliminating mistakes (Isaac et al., 2016). In view of the current COVID-19 pandemic that moves learning systems away from the traditional way to the online and distance learning, the current emphasis is on determining the impact of such challenges on students' performance. Thus, in this research, the performance impact is described based on knowledge acquisition, competence, productivity and resource savings (Isaac et al., 2017)

\section{Conceptual framework and hypotheses development}

\section{Overall quality}

Quality in social sciences one of the extremely difficult terms to define particularly in the context of e-services. Santos (2003) described the concept as a judgement of excellence and overall benefits received by the customer. Furthermore, the concept has been evolved in educational institutions (Brochado, 2009), due to the challenging environment that enforce universities to put more efforts to cope with the competitive environment and deliver quality of their educational services (Ijaz, et al., 2011). Particularly, as a result of the current COVID-19 challenges and sophisticated OLSs that arouse the need to deliver functionally quality service. Therefore, the students' evaluation of the delivered educational e-service has now become crucial. In particular, student satisfaction, student engagement, student actual use and student performance supposed to be consequences for delivering high OLS. A meaningful positive link between the service quality and satisfaction has been drawn by many scholars. Universities have explored that educational services should be treated as a business in terms of focusing on their 
customers; therefore, they must consider their students' expectations and perceived quality (Ijaz et al., 2011). According to Cronin et al., (2000), a causal link exists between educational service quality, student satisfaction and performance. Furthermore, student engagement (Ding et al., 2017) and actual use (Isaac et al., 2019) have been as outcomes for the high quality delivered educational service. Cheng (2012), emphasized that using mobile learning enhance engagement and communication through providing immediate access to information. Therefore, it is worth investigating whether the quality of OLS still has the same effect or not. This research suggests that the greater overall quality of the OLS, the higher student satisfaction, the higher student engagement, the higher actual use and higher performance.

H1: Overall quality significantly and directly influences student satisfaction.

H2: Overall quality significantly and directly influences student engagement.

H3: Overall quality significantly and directly influences actual use

H4: Overall quality significantly and directly influences performance impact.

\section{Student satisfaction}

In the higher education sector, satisfaction considered one of the most important antecedents of superior performance whether from students' point of view or from the faculties' point of view (Nadiri et al., 2009). When it comes to students, their satisfaction will depend on meeting or exceeding their expectations regarding the course, materials, instructor and teaching method (Rueda et al., 2017). While several studies (Isaac et al., 2017; Stefanovic et al.,

Vol.2, No.1, Part 1., Jan. 2021396 
2016) have emphasized the positive impact of user satisfaction on performance in numerous contexts, Daud (2011) cut down the significant relationship between satisfaction and performance impact. However, understanding the various levels of students' satisfaction explain the divergent levels of students' performance (Yilmaz, 2017b). Furthermore, high levels of satisfaction have been firmly connected to desired levels of outcomes. According to Alves and Raposo (2007), the consequences of satisfaction in higher education go beyond the consequences in other service sectors. The researchers emphasized the positive impact of satisfaction on loyalty and positive word of mouth. Since our focus in this research is the student, it is reasonable to expect student satisfaction to affect performance. Additionally, "higher system quality is expected to lead to higher user satisfaction use, leading to positive impacts on individual performance" (Kuh \& Schneider, 2008a; p.11).

H5: Student satisfaction significantly and directly influences performance impact

H6: Student satisfaction mediates the relationship between overall quality and performance impact

\section{Student engagement}

Student engagement can be understood by the active participation of students during learning activities. According to Kuh (2008), student engagement one of the important factors for learning that has many positive outcomes for students. "it is an umbrella term which brings together students' degree of attention, curiosity, interest and willingness to employ their language proficiency and a repertoire of learning skills to make progress" (Zhang \& Hyland, 2018; p. 91). Therefore, some evidence of positive student outcomes has been positively linked to student engagement (Pascarella et al., 
2010). Students who are engaged, are intrinsically motivated to learn, participate in study activities, ask questions, enjoy learning challenges which push them to achieve superior performance (Bakker et al., 2015). Enhancing student engagement increases students' abilities of critical thinking and improve problem-solving skills (Liaw et al., 2007). However, vast majority of the studies have examined student engagement in classrooms whether these studies concentrated on the antecedents of student engagement (Kuh \& Schneider, 2008a) or consequences of student engagement (Chen et al., 2008; Kuh et al., 2008; Pascarella et al., 2010; Quaye \& Harper, 2014). In the present study, we investigate the engagement during distance learning and its impact on student performance. Moreover, we follow the D\&M model of IS where we suppose the higher perceived overall quality leads to higher performance impact if students more engaged.

H7: Student engagement significantly and directly influences performance impact

H8: Student engagement exerts a mediating effect on the association between overall quality and performance impact

\section{Actual use}

Actual use refers to the extent to which individuals can use information system functions (DeLone \& McLean, 2016). When it comes to online learning, actual use reflects the frequency of use and the period of use (Kim et al., 2007). While some studies have utilized using of OLS online as a final dependent variable (Islam, 2013), other researchers investigated the impact of real usage on user satisfaction and performance (Son et al., 2012). However, a significant positive association between actual use and performance as well as satisfaction was established (Isaac et al., 2017). On 
contrary, other researchers have reported the insignificant impact of actual use on satisfaction and performance (Cho et al., 2015; Wu \& Wang, 2006). We argue that understanding and using the online system plays an antecedent role for student satisfaction and performance. According to Islam (2013), actual use of e-learning system helps students to learn easily where they need to do a minimal effort for learning activities. Furthermore, actual use of e-learning system increases learning outcomes in three ways: boosts engagement (Liaw et al., 2007), fasts information sharing (Ortiz et al., 2004); and enhances self-learning opportunities (Leidner \& Jarvenpaa, 1995). Islam (2013) consistently reported that the use of e-learning systems leads to students' effectiveness by providing them with self-learning opportunities. It is thus reasonable to expect that actual use of the OLS will positively enhance student satisfaction, performance and amplifies the impact of overall quality on performance.

H9: Actual usage significantly and directly influences student satisfaction.

H10: Actual usage significantly and directly influences performance impact.

H11: Actual use mediates the relationship between overall quality and performance impact.

The proposed model and developed hypotheses are presented in the following figure. 


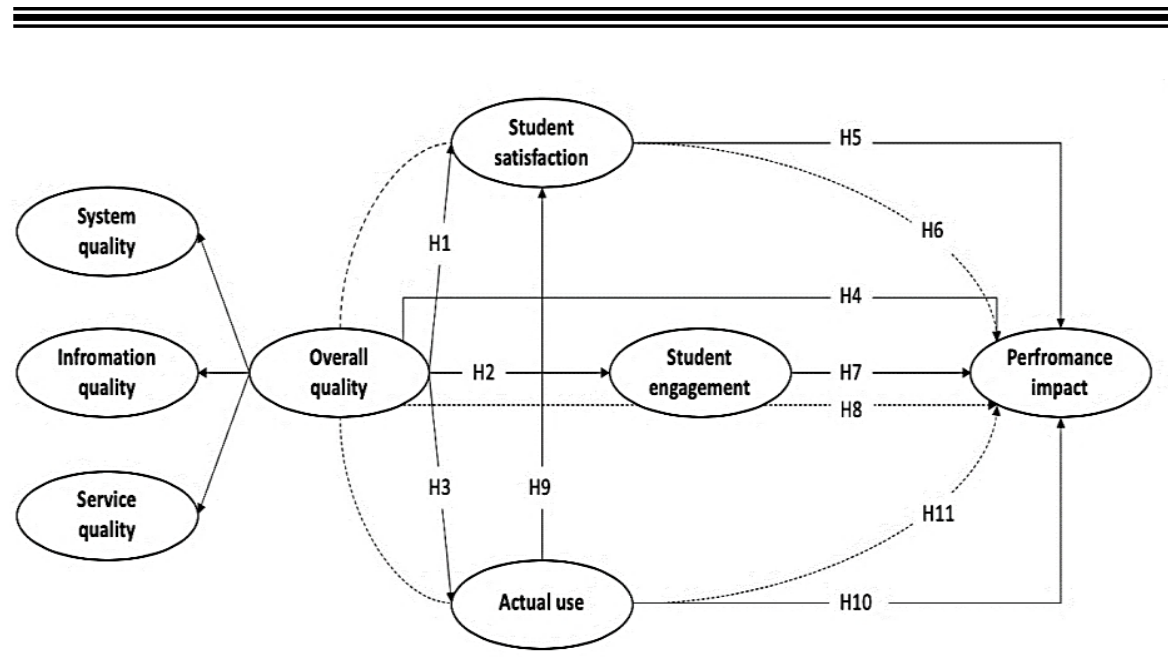

Figure 2: Conceptual model

\section{Research methods}

\section{Sample and data collection}

The subjects of this study are students enrolled in public universities in Egypt at both undergraduate and postgraduate levels. At a confidence level of $95 \%$, the calculated sample size is 384 which is more than the minimum sample size of 300 required to use the SEM in data analysis. This study relied on convenience sampling. The data is collected using online self-administrated survey, an invitation was sent to respondents on WhatsApp with the access link to the online survey. Direct translation was used to translate the questionnaire from English language to Arabic. Data was collected over a period of one-month starting from the first of April 2020, the survey was thus spanning during these four weeks. It worthwhile that the data collection started shortly after the suspension of education in the Universities due to the Coronavirus; therefore, students at both levels; undergraduate and postgraduate, were oriented toward the use of e-learning system. During this 
period all the students were experiencing distant learning using the e-learning system provided by the Public Universities in Egypt. The final sample $(\mathrm{N}=781)$ consists of 353 female and 428 male constituting $45.2 \%$ and $54.8 \%$ respectively. The majority of the students are undergraduate representing $59 \%$ of the sample.

\section{Measures}

All the measurement scales were drawn from prior studies. The questionnaire was developed in two-sections: the first section included questions relating to the key study constructs, while the second section comprised questions pertaining to the respondent's demographic information, their faculties and experience with using online learning. All the items were measured on 7-point Likert scale ranged from "strongly disagree" (1) to "strongly agree" (7)

\section{Data analysis and results}

\section{Measurement model}

The data was analyzed using SmartPLS method, as a prerequisite the validity and reliability were firstly assessed. The constructs convergent validity was evaluated by assessing the factor loading. Of the 37 items used, only 33 items had loading estimates higher than 0.5 with significant $t$-values $(\mathrm{p}<0.001)$. The average variance extracted (AVE) was above the minimum of 0.5 for all constructs. The internal consistency was considered good, both Cronbach alpha and composite reliability estimates were above the threshold of 0.7 indicating acceptable reliability. Table 1 provides supportive data for convergent validity and internal consistency reliability. The comparison of AVE values with the square of the 
correlation estimate between constructs verified the existence of discriminate validity for most of the constructs but two. The two constructs of student engagement and performance did not meet the Fornell and Larcker criterion of discriminant validity. Accordingly, the new HTMT (Heterotrait-monotrait) ratio evidenced with high sensitivity rates was used to identify discriminant validity effectively unlike the Forenll and Larceker criterion suffering from having an unacceptable low sensitivity. We first use HTMT as a criterion with threshold 0.90, all the values for all pairs of reflective constructs were below this figure. Second, the bootstrapping procedure was applied for examining the confidence intervals for the HTMT, the results support the alternative hypothesis (H1: HTMT $<1)$; thus, validating that the two constricts are empirically distinct (Kock, 2015). The HTMT results are shown in table 2.

In the context of SEM-PLS, common method bias is caused by the measurement method. The validation of convergent and discriminant validity is not effective to verify the lack of common method bias; however, the full collinearity test is proposed to be an alternative method.

Accordingly, it is proposed that the occurrence of a variance inflations factors (VIFs) is an indication of method biasedness. The results indicate that the model is free of common method bias as the values of VIFs resulting from full collinearity test met the cut-off point $(\leq 3.3)$. 
Scientific Journal for Financial and Commercial Studies and Researches

Dr. Reham Shawky Ebrahim; Dr. Waleed Afify \& Dr Reda Abdelkareem

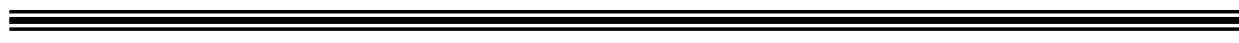

Table 1: The measurement model statistics

\begin{tabular}{|c|c|c|c|c|c|c|}
\hline & \multicolumn{2}{|c|}{ Descriptive statistics } & & \multirow[b]{2}{*}{ AVE } & \multirow[b]{2}{*}{$\begin{array}{c}\text { Composite } \\
\text { reliability }\end{array}$} & \multirow[b]{2}{*}{$\begin{array}{l}\text { Cronbach } \\
\text { alpha }\end{array}$} \\
\hline Indicators & Mean & $\mathrm{SD}$ & $\begin{array}{c}\text { Factor } \\
\text { loading }\end{array}$ & & & \\
\hline \multicolumn{7}{|c|}{ System quality } \\
\hline Sysq 1 & \multirow[t]{3}{*}{2.3378} & \multirow[t]{3}{*}{1.08928} & 0.904 & \multirow[t]{3}{*}{0.810} & \multirow[t]{3}{*}{0.927} & \multirow[t]{3}{*}{0.883} \\
\hline Sysq 2 & & & 0.906 & & & \\
\hline Ssysq 4 & & & 0.890 & & & \\
\hline \multicolumn{7}{|c|}{ Information quality } \\
\hline Infq 1 & \multirow[t]{5}{*}{2.3953} & \multirow[t]{5}{*}{1.25625} & 0.851 & \multirow[t]{5}{*}{0.728} & \multirow[t]{5}{*}{0.930} & \multirow[t]{5}{*}{0.900} \\
\hline Infq 2 & & & 0.794 & & & \\
\hline Infq 3 & & & 0.864 & & & \\
\hline Infq 4 & & & 0.865 & & & \\
\hline Infq 5 & & & 0.890 & & & \\
\hline \multicolumn{7}{|c|}{ Service quality } \\
\hline Serq 1 & \multirow[t]{4}{*}{2.2431} & \multirow[t]{4}{*}{1.09324} & 0.889 & \multirow[t]{4}{*}{0.778} & \multirow[t]{4}{*}{0.934} & \multirow[t]{4}{*}{0.900} \\
\hline Serq 2 & & & 0.882 & & & \\
\hline Serq 3 & & & 0.903 & & & \\
\hline Serq 5 & & & 0.855 & & & \\
\hline \multicolumn{7}{|l|}{ Satisfaction } \\
\hline Satis 1 & \multirow[t]{3}{*}{1.8974} & \multirow{3}{*}{1.13504} & 0.926 & \multirow{3}{*}{0.838} & 0.939 & 0.803 \\
\hline Satis 2 & & & 0.925 & & & \\
\hline Satis 3 & & & 0.894 & & & \\
\hline Actual use & & & & & & \\
\hline Actuse 1 & 1.8801 & 1.21833 & 0.932 & 0.851 & 0.945 & 0.812 \\
\hline Actuse 2 & & & 0.926 & & & \\
\hline Actuse 3 & & & 0.909 & & & \\
\hline Performance & pact & & & & & \\
\hline Spei_4 & 2.1136 & 1.19301 & 0.936 & 0.758 & 0.969 & 0.864 \\
\hline Spei 5 & & & 0.929 & & & \\
\hline Spei 7 & & & 0.932 & & & \\
\hline Spei_8 & & & 0.908 & & & \\
\hline Spei_9 & & & 0.945 & & & \\
\hline Spei_10 & & & 0.936 & & & \\
\hline Engagement & & & & & & \\
\hline Seng_1 & 1.09324 & 2.2431 & 0.883 & 0.782 & 0.962 & 0.953 \\
\hline Seng_2 & & & 0.901 & & & \\
\hline Seng_3 & & & 0.911 & & & \\
\hline Seng_4 & & & 0.923 & & & \\
\hline Seng_5 & & & 0.896 & & & \\
\hline Seng_6 & & & 0.900 & & & \\
\hline
\end{tabular}

Vol.2, No.1, Part 1., Jan. 2021403 
Scientific Journal for Financial and Commercial Studies and Researches

Dr. Reham Shawky Ebrahim; Dr. Waleed Afify \& Dr Reda Abdelkareem

\begin{tabular}{|c|c|c|c|c|c|}
\hline \hline \multicolumn{6}{|c|}{ Table 2: Discriminant validity (HTMT-results) } \\
\hline & $\begin{array}{c}\text { Overall } \\
\text { quality }\end{array}$ & SATIS & $\begin{array}{c}\text { ACTUS } \\
\text { E }\end{array}$ & SPEI & SENG \\
\hline $\begin{array}{c}\text { Overall } \\
\text { quality }\end{array}$ & & & & & \\
\hline SATIS & 0.834 & & & & \\
\hline ACTUSE & 0.899 & 0.853 & & & \\
\hline SPERI & 0.884 & 0.807 & 0.821 & & \\
\hline SENG & 0.807 & 0.814 & 0.853 & 0.842 & \\
\hline
\end{tabular}

\section{Hypotheses testing}

The structural model was assessed to test the hypotheses developed. The explanatory power of the model is $86 \%$, which means that predictive power of the predictors (actual use, student satisfaction and student engagement) explains a significant amount of variance for student performance impact. All the hypotheses were supported at a significant level of 0.01 , as reported in table 3 . 
Scientific Journal for Financial and Commercial Studies and Researches

Dr. Reham Shawky Ebrahim; Dr. Waleed Afify \& Dr Reda Abdelkareem

Table 3: Hypotheses testing

\begin{tabular}{|c|c|c|c|c|}
\hline Hypotheses & Path & $\beta$ & t-value & $p$-value \\
\hline \multicolumn{5}{|c|}{ Direct impacts of overall quality } \\
\hline $\mathrm{H} 1$ & $\begin{array}{l}\text { Overall quality } \rightarrow \text { student } \\
\text { satisfaction }\end{array}$ & 0.474 & 11.937 & 0.000 \\
\hline $\mathrm{H} 2$ & $\begin{array}{l}\text { Overall quality } \rightarrow \text { student } \\
\text { engagement }\end{array}$ & 0.867 & 62.927 & 0.000 \\
\hline $\mathrm{H} 3$ & $\begin{array}{l}\text { Overall quality } \rightarrow \text { actual } \\
\text { use }\end{array}$ & 0.84 & 51.315 & 0.000 \\
\hline $\mathrm{H} 4$ & $\begin{array}{l}\text { Overall quality } \rightarrow \\
\text { performance impact }\end{array}$ & 0.109 & 2.428 & 0.016 \\
\hline H5 & $\begin{array}{l}\text { Student satisfaction } \rightarrow \\
\text { performance impact }\end{array}$ & 0.128 & 2.751 & 0.006 \\
\hline $\mathrm{H} 7$ & $\begin{array}{l}\text { Student engagement } \rightarrow \\
\text { performance impact }\end{array}$ & 0.51 & 11.235 & 0.000 \\
\hline H9 & $\begin{array}{l}\text { Actual use } \rightarrow \text { student } \\
\text { satisfaction }\end{array}$ & 0.469 & 11.525 & 0.000 \\
\hline $\mathrm{H} 10$ & $\begin{array}{l}\text { Actual use } \rightarrow \\
\text { performance impact }\end{array}$ & 0.225 & 5.544 & 0.000 \\
\hline \multicolumn{5}{|c|}{ Indirect impacts } \\
\hline H6 & $\begin{array}{l}\text { Overall quality } \rightarrow \text { student } \\
\text { satisfaction } \rightarrow \\
\text { performance impact }\end{array}$ & 0.061 & 2.56 & 0.011 \\
\hline H8 & $\begin{array}{l}\text { Overall quality } \rightarrow \text { student } \\
\text { engagement } \rightarrow \\
\text { performance impact }\end{array}$ & 0.442 & 11.044 & 0.000 \\
\hline H11 & $\begin{array}{l}\text { Overall quality } \rightarrow \text { actual } \\
\text { use } \rightarrow \text { performance } \\
\text { impact }\end{array}$ & 0.189 & 5.43 & 0.000 \\
\hline
\end{tabular}

Vol.2, No.1, Part 1., Jan. 2021405 


\section{Test of significant paths}

As expected, the system's overall quality measured by three dimensions: system quality, informational quality and service quality, has a significant direct positive influence on student satisfaction with $(\beta=0.474, \mathrm{p}<0.001$, t-value $=11.937)$, student engagement $(\beta=0.867, p<0.001, \mathrm{t}$-value $=62.927)$ and actual use $(\beta=0.84, p<0.001, t-v a l u e=51.315)$. Thus, supporting hypotheses H1-H3. The overall quality substantially explains $67.8 \%, 60.6 \%$ and $59.4 \%$ of the variations in satisfaction, engagement and actual use respectively. With respect to the relationship between overall quality and performance impact, the results reveal the significant direct impact of overall quality on performance impact $(\beta=0.109, p<0.01$, $\mathrm{t}$-value $=2.428$ ); supporting H4. Additionally, performance impact was also found to be significantly and directly affected by student satisfaction $(\beta=0.128, p<0.01$, $t$-value $=2.751)$, student engagement $(\beta=0.51, p<0.001, \mathrm{t}$-value $=11.235)$ and actual use $(\beta=0.225$, $\mathrm{p}<0.001$, $\mathrm{t}$-value $=5.544)$; thus, supporting H5, H7 and H10. Actual use has a positive direct impact on student satisfaction $(\beta=0.469$, $\mathrm{p}<0.001, \mathrm{t}$-value $=11.525$ ), H9 is supported as well. The indirect relationships were also significant. The results support the mediation of student satisfaction, engagement and actual use in the relationship between overall quality and performance impact. The hypotheses $\mathrm{H} 6$ $(\beta=0.061, p=0.011, \mathrm{t}-\mathrm{value}=2.56)$., H8 $(\beta=0.442, \mathrm{p}=0.000$, $\mathrm{t}-$ value $=11.044)$, and $\mathrm{H} 11(\beta=0.189, \mathrm{p}=0.000, \mathrm{t}$-value $=5.43)$ are all supported. From the path coefficients of direct relationships, among the four predicators of performance impact, student's engagement has the highest the relative importance, followed by actual use, then student satisfaction and finally overall quality. However, the mediation effect increases the total effects of overall quality on performance impact to 0.551 when mediated by student engagement. While, the mediation of student satisfaction and actual use increase the effect of overall quality on performance impact to 0.17 and 0.298 respectively. 
Scientific Journal for Financial and Commercial Studies and Researches

Dr. Reham Shawky Ebrahim; Dr. Waleed Afify \& Dr Reda Abdelkareem

IPMA

The importance-performance map analysis, examines the importance and performance of an exogenous variable in anticipating the target endogenous variable by estimating the total unstandardized effect (Höck et al., 2010). As indicated in figure 2, the importance-performance map of student's performance impact, the $\mathrm{x}$-axis reflects the importance of the construct measured by the total effects whereas the $y$-axis reflects it performance with the mean value of scores ranging from $0-100$. The results revealed that all the latent variables have low performance below the average; however, the importance of overall quality and student engagement are above the average. The total effect of 0.908 indicates the importance of overall quality; hence, an increase in overall quality by one unit will increase the performance of students by 0.908 points. The student engagement construct with total effect of 0.527 , indicates its high importance as well. It is suggested that in order to increase student performance, priority should be given first to the overall quality of the OLS followed by enhancement of student engagement. 
Scientific Journal for Financial and Commercial Studies and Researches

Dr. Reham Shawky Ebrahim; Dr. Waleed Afify \& Dr Reda Abdelkareem

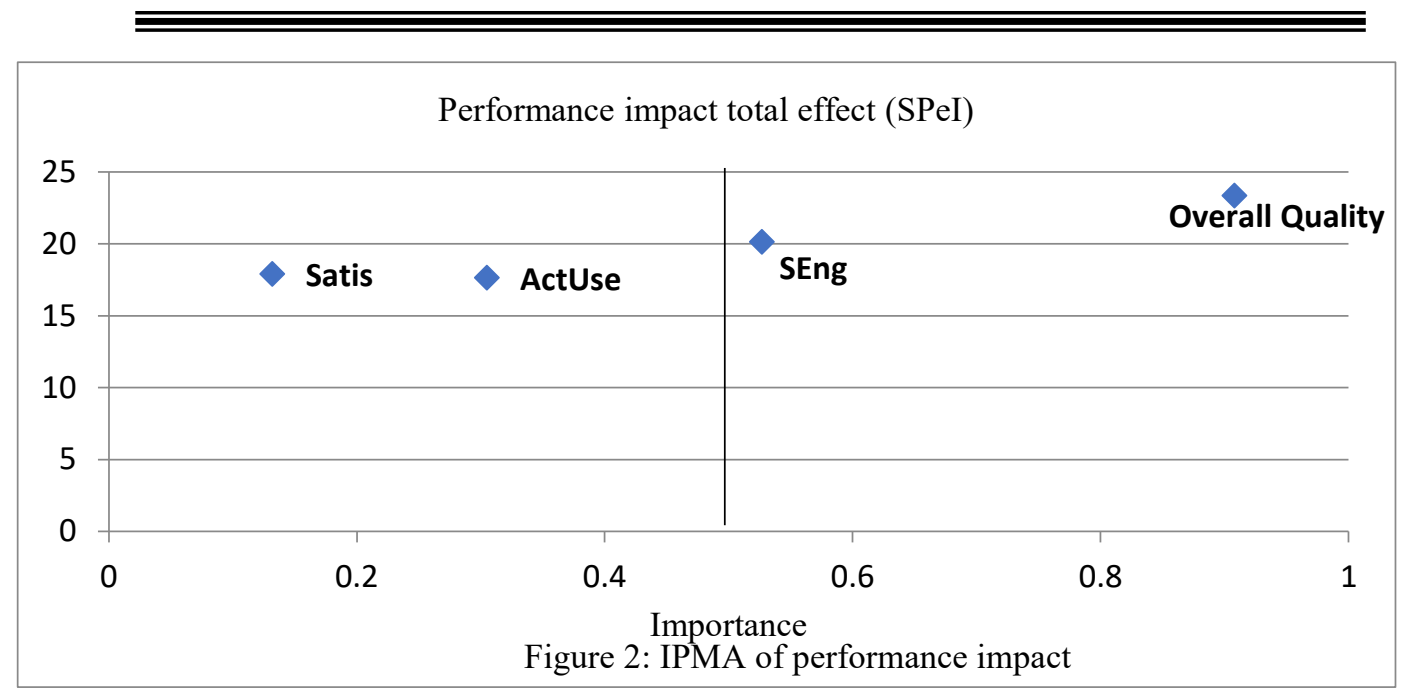

Figure 2: IPMA of performance impact

\section{Discussion}

This study adopts the D\&M model to go beyond the actual use to assess the quality of the OLS and its impact on student engagement and their performance. Based upon, the overall quality dimensions; identified by the system quality, information quality and service quality, are defined as individual's beliefs about the elearning system that affect their attitude toward the system and behaviors. The model was thus extended and used to understand the student's psychological state of being involved in the e-learning system and his/her performance. In the proposed model, the elearning overall quality aspects were used as the extrinsic factors affecting student's intrinsic motivations to experience the system, reflected by engagement, which in turn will affect the performance. The model was empirically tested and validated, and the results support the followings. 
Firstly, the study supported the beliefs-attitude-use relationship expressed in the D\&M model, as the results reveal the positive direct significant impact of overall quality on students' satisfaction and actual use. It thus came into consistent with prior studies that utilize the D\&M model in the context of online or distant learning (Cronin et al., 2000). The success of the e-learning system is accredited to the dimensions of overall quality including system quality described by reliability, accessibility and usability, information quality described by accuracy, relevancy, completeness, trendiness and personalization, and finally service quality described by tangibility, functionality, interactivity and responsiveness. To improve the success of e-learning implementation and its use, these are dimensions that should be assessed closely. Similarly, (Bagozzi (1992) supports in his study the direct and indirect paths of quality aspects. The direct relationships add value to the importance of the overall quality of the e-learning system emphasized by the technical, semantic and service provider success. While, it plays a significant role in shaping user's perceptions toward the system; hence it is considered an important criterion in decision-making process for students. The successfulness of the e-learning system increases student's satisfaction and intentions to use or actual use which in turn increases the net benefits of the system and its effectiveness reflected in student performance.

Secondly, the study demonstrates the significance of integrating student engagement to the D\&M model and supports its impact on performance impact; thus, explore engagement antecedents and outcomes. The results refine the measurement of student engagement and emphasis two aspects; the cognitive and emotional. The importance of these two aspects over other the academic and behavioral engagement has been highlighted in the study of (Chen et al., 2008). They noted that cognitive and emotional engagement are related to intrinsic motivations in response to several 
contextual factors and are associated with positive learning outcomes. Consistently, the findings of this study support the role of the e-learning system in motivating students to interact with it and got engaged in the learning process; thus, enhancing their performance. Student engagement with distant learning is effective and satisfactory than campus-based education (Kuh et al., 2008; Zhang \& Hyland, 2018)The high levels of engagement foster the academic achievements and its persistence to the extent that it can diminish the varying impact of previous experiences and background. These levels can be attained by student interactions with the e-learning system, the content and the programs, and by the interventions and practices of teachers or staff members.

Thirdly, the antecedents of student performance using the elearning system were examined in this study. Actual use and satisfaction are having a meaningful direct effect on performance impact; additionally, the relationship between actual use and satisfaction was also revealed to be significant. Thus, it is suggested that the rate of use and the longest duration students tend to spend on e-learning system will create a positive attitude toward the system and improve academic proficiency. Also, the greater the satisfaction with the e-learning system and the service provider in meeting student expectations will eventually improve performance. The direct effects of satisfaction and actual use and the indirect effects; mediating the relationship between the overall quality and performance impact (net benefits at the individual impact), are validated in the D\&M model. However, the findings contribute to the extant literature by revealing the relative importance of student engagement over satisfaction and actual use directly and indirectly. Student engagement direct impact on performance is higher than actual use and satisfaction, it also enhances the total impact of the system's overall quality on performance. Although, the findings of Rueda et al. (2017) reveal a weak direct effect of traditional 
education technology on student engagement; however, the mediating role of student engagement linking OLS use and benefits, is starting to get a wide support (Francescucci \& Rohani, 2019). The academic performance of students using OLS is a function to their level engagements and interactions with the system, attitudes and behaviors, and is an indicator to the effectiveness of the system itself.

\section{Theoretical implications}

First, this study empirically verifies the D\&M model in the field of online learning. The model in higher education sector; however, it was not investigated during crisis times in which there are no alternatives for OL or distance learning. Our study validates students' perceptions for overall quality of OLS and addresses the link between the overall quality and student engagement, student satisfaction, actual use and performance impact.

Second, this study enriches the literature of the information system by incorporating student engagement in the model. Our study extends the D\&M model through the addition of student engagement. The use of student engagement as a mediating construct is one of the first attempts within the distance learning context. It may, therefore, be classified as a significant contribution to the information system model.

Third, our study explains theoretically and demonstrates empirically antecedents and outcomes of student engagement in distance learning, and demonstrated the importance of the cognitive and emotional aspects of student engagement over the behavioral aspect. Moreover, it emphasizes how online education quality increases student satisfaction and the actual use of the e-learning system. With respect to the variation in students' academic performance that can be attributed to previous experiences and background, the study theoretically explained how high levels of student engagement foster academic achievements. Additionally, the 
performance impact is not determined by the academic achievement captured only by course grades, but the study investigated how the use of OLS can enhances an individual performance, competence, knowledge, decision making and communication skills. Therefore, the value of depending on technology-based learning has a long-term impact that extends beyond the course grades and academic success to affect the effectiveness and efficiency of job at the organizational level.

Fourth, valuable indirect relationships have been theoretically contributed and empirically demonstrated by this research. For instance, the outcomes have addressed the mediating role of student satisfaction in the relationship between overall quality and performance impact. According to (Rueda et al., 2017), meeting or exceeding student expectation determine the level of student's satisfaction; however, the various levels of students' satisfaction explain the divergent levels of students' performance (Yilmaz, 2017a). Furthermore, there is a mediating impact for actual use in the relationship between overall quality and performance impact. According to Islam (2013), the actual use of the e-learning system increases students' effectiveness. This effectiveness supposed to be reflected in the superior performance which has been demonstrated by the results of this research. Finally, there is an indirect impact of overall quality on the performance impact mediated by the level of student engagement.

\section{Managerial implications}

The managerial implications of this research are quadruple. First, the results of this research help universities and quality assurance bodies to realize the overall OLS quality perceived by the students in which they can know the aspects of development. Secondly, the extended D\&M IS success model provides a deeper understanding of the key success dimensions and their 
interrelationships. It also implies that a good beneficial system is not only determined by the actual use but also on its ability to motivate learner engagement; hence, universities are recommended to promote student engagement to make the most of OLS quality impact on students' performance. Thirdly, the findings encourage policy makers to promote the use of distance learning even in normal times where there are no crises (e.g. COVID-19 pandemic). Such hectic times could be repeated in the future; thus, universities would be ready to deal with it. Therefore, the model of this study should be promoted and supported for future policy not only at the organizational level but also at the national level. Finally, the findings of this research have emphasized that student satisfaction is a consequence for the actual use of the system; therefore, students, universities, and interested authorities and advised to use and promote the OLS first before judging students' satisfaction.

\section{Limitations and future research}

It is acknowledged that there are various limitations in this research that open new avenues for future research. First, despite the comprehensive definition of student engagement has been observed to cover three interrelated aspects cognitive, behavioral, and emotional or even four distinct aspects: academic, behavioral, cognitive and emotional. This study has considered only the emotional and cognitive dimensions to verify validity and reliability limitations. Thus, further research needs to incorporate the other dimension(s) to satisfy the comprehensive definition of student engagement. Second, the data of this research were collected using an online self-administrated survey due to the constraints of coronavirus that cut off all kind of face-to-face communications. Qualitative research methods that adopt in-depth interviews could be used in future examinations. Conducting semi-structured interviews 
with students about their perceptions of OL system quality will generate data that direct instructional universities to the ways in which they improve educational service quality. Furthermore, measuring student satisfaction qualitatively by doing semistructured interviews could validate such important and frequently used measurement appropriately. Third, the study was carried out with both ungraduated and postgraduate students enrolled at public universities in Egypt. Further research would make a comparison between public and private universities. It would be useful to measure students' perceptions of OLS quality, students' engagement, students' satisfaction and students' performance in private universities and compare it with the public universities where the private ones have more resources, facilities and capabilities than the public ones. Finally, this research was conducted within the higher education sector in one country (Egypt). While this study introduces valuable contributions, it may not be generalizable to all education systems. It is worth further research to replicate this study across different education systems (primary, secondary), different student circumstances (part-time, full time), different age groups, different student disciplines (medical students, business students, education students, etc.) with a representative sample that include and compare the performance variation for each discipline. Replicating this research in a different geographical domain or collecting data from more than one country would be valuable as well to expand the scope of the study and generalizability considerations. 
Scientific Journal for Financial and Commercial Studies and Researches

Dr. Reham Shawky Ebrahim; Dr. Waleed Afify \& Dr Reda Abdelkareem

\section{References}

Aldholay, A. H., Abdullah, Z., Ramayah, T., Isaac, O., \& Mutahar, A. M. (2018). Online learning usage and performance among students within public universities in Yemen. In Int. J. Services and Standards (Vol. 12, Issue 2).

Alves, H., \& Raposo, M. (2007). Conceptual Model of Student Satisfaction in Higher Education. Total Quality Management \& Business $\quad$ Excellence, 18(5), 571-588. https://doi.org/10.1080/14783360601074315

Appleton, J. J., Christenson, S. L., Kim, D., \& Reschly, A. L. (2006). Measuring cognitive and psychological engagement: Validation of the Student Engagement Instrument. Journal of School Psychology, 44(5), 427-445. https://doi.org/10.1016/j.jsp.2006.04.002

Araújo, F. J. de O., de Lima, L. S. A., Cidade, P. I. M., Nobre, C. B., \& Neto, M. L. R. (2020). Impact Of Sars-Cov-2 And Its Reverberation In Global Higher Education And Mental Health. Psychiatry Research, 288, 112977. https://doi.org/10.1016/j.psychres.2020.112977

Bagozzi, R. P. (1992). The Self-Regulation of Attitudes, Intentions, and Behavior. Social Psychology Quarterly, 55(2), 178. https://doi.org/10.2307/2786945

Bakker, A. B., Sanz Vergel, A. I., \& Kuntze, J. (2015). Student engagement and performance: A weekly diary study on the role of openness. Motivation and Emotion, 39(1), 49-62. https://doi.org/10.1007/s11031-014-9422-5

Bond, M., Buntins, K., Bedenlier, S., Zawacki-Richter, O., \& Kerres, M. (2020). Mapping research in student engagement and educational technology in higher education: a systematic evidence map. International Journal of Educational Technology in Higher Education, 17(1), 2. https://doi.org/10.1186/s41239-019-0176-8 
Carini, R. M., Kuh, G. D., \& Klein, S. P. (2006). Student Engagement and Student Learning: Testing the Linkages*. Research in Higher Education, 47(1), 1-32. https://doi.org/10.1007/s11162-005-8150-9

Chen, H.-J. (2010). Linking employees' e-learning system use to their overall job outcomes: An empirical study based on the IS success model. Computers \& Education, 55(4), 1628-1639. https://doi.org/10.1016/j.compedu.2010.07.005

Chen, P.-S. Daniel., Gonyea, R., \& Kuh, G. (2008). Learning at a Distance: Engaged or Not? Innovate: Journal of Online Education, 4(3).

Cheng, Y. (2012). Effects of quality antecedents on e-learning acceptance. Internet Research, 22(3), 361-390. https://doi.org/10.1108/10662241211235699

Cheok, M. L., \& Wong, S. L. (2015). Predictors of e-learning satisfaction in teaching and learning for school teachers: A literature review. International Journal of Instruction, 8(1), 75-80.

Cho, K. W., Bae, S.-K., Ryu, J.-H., Kim, K. N., An, C.-H., \& Chae, Y. M. (2015). Performance Evaluation of Public Hospital Information Systems by the Information System Success Model. Healthcare Informatics Research, 21(1), 43. https://doi.org/10.4258/hir.2015.21.1.43

Crawford, J., Butler-Henderson, K., Rudolph, J., Malkawi, B., Glowatz, M., Burton, R., Magni, P., \& Lam, S. (2020). COVID-19: 20 countries' higher education intra-period digital pedagogy responses. Journal of Applied Learning \& Teaching, 3(1). https://doi.org/10.37074/jalt.2020.3.1.7

Cronin, J. J., Brady, M. K., Tomas, G., \& Hult, M. (2000). Assessing the Effects of Quality, Value, and Customer Satisfaction on Consumer Behavioral Intentions in Service Environments. Journal of Retailing, 76(2), 193-218.

Daud, N. M. (2011). Determining critical success factors of mobile banking adoption in Malaysia. Australian Journal of Basic and

Vol.2, No.1, Part 1., Jan. 2021416 
Scientific Journal for Financial and Commercial Studies and Researches

Dr. Reham Shawky Ebrahim; Dr. Waleed Afify \& Dr Reda Abdelkareem

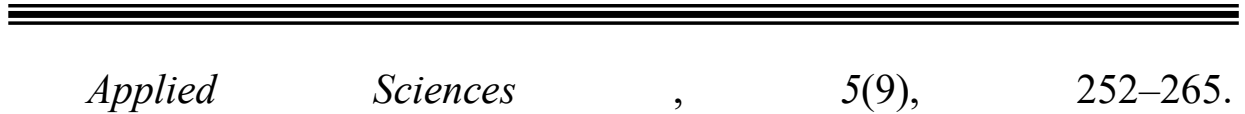

https://doi.org/10.1108/10650740910984637

Delone, W. H., \& Mclean, E. R. (2003). The DeLone and McLean Model of Information Systems Success: A Ten-Year Update. In Information Systems Research, Journal of Management Information Systems (Vol. 19, Issue 4).

DeLone, W. H., \& McLean, E. R. (2016). Information Systems Success Measurement. Foundations and Trends ${ }^{\circledR}$ in Information Systems, 2(1), 1-116. https://doi.org/10.1561/2900000005

Ding, L., Kim, C., \& Orey, M. (2017). Studies of student engagement in gamified online discussions. Computers \& Education, 115, 126-142. https://doi.org/10.1016/j.compedu.2017.06.016

Dunn, T. J., \& Kennedy, M. (2019). Technology Enhanced Learning in higher education; motivations, engagement and academic achievement. Computers and Education, 137, 104-113. https://doi.org/10.1016/j.compedu.2019.04.004

Francescucci, A., \& Rohani, L. (2019). Exclusively Synchronous Online (VIRI) Learning: The Impact on Student Performance and Engagement Outcomes. Journal of Marketing Education, 41(1), 6069. https://doi.org/10.1177/0273475318818864

Fredricks, J. A., Blumenfeld, P. C., \& Paris, A. H. (2004). School Engagement: Potential of the Concept, State of the Evidence. Review of Educational Research, 74(1), 59-109. https://doi.org/10.3102/00346543074001059

Goggins, S., \& Xing, W. (2016). Building models explaining student participation behavior in asynchronous online discussion. Computers \& Education, 94, 241-251. https://doi.org/10.1016/j.compedu.2015.11.002

Halonen, R., Acton, T., Golden, W., \& Conboy, K. (2009, April 26). DeLone \& McLean success model as a descriptive tool in evaluating the use of a virtual learning environment. Paper Presented at 
Scientific Journal for Financial and Commercial Studies and Researches

Dr. Reham Shawky Ebrahim; Dr. Waleed Afify \& Dr Reda Abdelkareem

International Conference on Organizational Learning, Knowledge and Capabilities (OLKC 2009). http://hdl.handle.net/10379/222

Handelsman, M. M., Briggs, W. L., Sullivan, N., \& Towler, A. (2005). A Measure of College Student Course Engagement. The Journal of Educational Research, 98(3), 184-192. https://doi.org/10.3200/JOER.98.3.184-192

Hew, K. F., \& Cheung, W. S. (2014). Students' and instructors' use of massive open online courses (MOOCs): Motivations and challenges. Educational Research Review, 12, 45-58. https://doi.org/10.1016/j.edurev.2014.05.001

Höck, C., Ringle, C. M., \& Sarstedt, M. (2010). Management of multipurpose stadiums: importance and performance measurement of service interfaces. In Int. J. Services Technology and Management (Vol. 14, Issue 3). www.smartpls.de

Hsu, M. H., Chang, C. M., Chu, K. K., \& Lee, Y. J. (2014). Determinants of repurchase intention in online group-buying: The perspectives of DeLone \& McLean is success model and trust. Computers in Human Behavior, 36, 234-245. https://doi.org/10.1016/j.chb.2014.03.065

Hubble, S., \& Bolton, P. (2020). Coronavirus: Update implications for the further and higher education sectors.

Iivari, J. (2005). An empirical test of the DeLone-McLean model of information system success. ACM SIGMIS Database, 36(2), 8-27. https://doi.org/10.1145/1066149.1066152

Ijaz, A., Irfan, S. M., Shahbaz, s., Awan, M., \& Sabir, M. (2011). AN EMPIRICAL MODEL OF STUDENT SATISFACTION: CASE OF PAKISTANI PUBLIC SECTOR BUSINESS SCHOOLS. https://www.researchgate.net/publication/268350598

Isaac, O., Abdullah, Z., Ramayah, T., Mutahar, A. M., \& Alrajawy, I. (2017). Towards a Better Uniderstanding of Interent Technology Usage by Yemeni Employees in the Public Sector: An Extension of the Task-Technology Fit (TTF) Model. Research Journal of Applied

Vol.2, No.1, Part 1., Jan. $2021 \quad 418$ 
Scientific Journal for Financial and Commercial Studies and Researches

Dr. Reham Shawky Ebrahim; Dr. Waleed Afify \& Dr Reda Abdelkareem

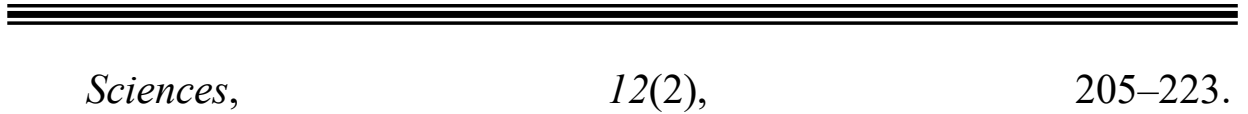

https://doi.org/10.3923/rjasci.2017.205.223

Isaac, O., Abdullah, Z., Ramayah, T., Mutahar, A. M., \& Alrajawy, I. (2016). Perceived Usefulness, Perceived Ease of Use, Perceived Compatibility, and Net Benefits: an empirical study of internet usage among employees in Yemen. In The 7th International Conference Postgraduate Education (ICPE7, 899-919.

Isaac, O., Aldholay, Adnan., Abdullah, Zaini., \& Ramayah, T. (2019). Online learning usage within Yemeni higher education: The role of compatibility and task-technology fit as mediating variables in the IS success model. Computers and Education, 136, 113-129. https://doi.org/10.1016/j.compedu.2019.02.012

Islam, A. K. M. N. (2013). Investigating e-learning system usage outcomes in the university context. Computers \& Education, 69, 387-399. https://doi.org/10.1016/j.compedu.2013.07.037

Jagannathan, V., Balasubramanian, S., \& Natarajan, T. (2018). An Extension to the Delone and Mclean Information Systems Success Model and Validation in the Internet Banking Context. In Encyclopedia of Information Science and Technology, Fourth Edition (pp. 49-60). https://doi.org/10.4018/978-1-5225-22553.ch004

Jung, Y., \& Lee, J. (2018). Learning Engagement and Persistence in Massive Open Online Courses (MOOCS). Computers \& Education, 122, 9-22. https://doi.org/10.1016/j.compedu.2018.02.013

Kahn, P. E. (2014). Theorising student engagement in higher education. British Educational Research Journal, 40(6), 1005-1018. https://doi.org/10.1002/berj.3121

Kock, N. (2015). Common method bias in PLS-SEM: A full collinearity assessment approach. International Journal of E-Collaboration, 11(4), 1-10.

Vol.2, No.1, Part 1., Jan. 2021 
Kong, S. C., \& Song, Y. (2015). An experience of personalized learning hub initiative embedding BYOD for reflective engagement in higher education. Computers \& Education, 88, 227-240. https://doi.org/10.1016/j.compedu.2015.06.003

Krause, K., \& Coates, H. (2008). Students' engagement in first-year university. Assessment \& Evaluation in Higher Education, 33(5), 493-505. https://doi.org/10.1080/02602930701698892

Kuh, G. D., Cruce, T. M., Shoup, R., Kinzie, J., \& Gonyea, R. M. (2008). Unmasking the Effects of Student Engagement on First-Year College Grades and Persistence. The Journal of Higher Education, 79(5), 540-563. https://doi.org/10.1080/00221546.2008.11772116

Kuh, G. D., \& Schneider, C. (2008a). High-Impact Educational Practices: What They Are, Who Has Access to Them, and Why They Matter. Association of American Colleges and Universities: Washington, DC.

Kuh, G. D., \& Schneider, C. (2008b). High-impact educational practices: what they are, who has access to them, and why they matter. Association of American Colleges and Universities: Washington, DC.

Lawson, M. A., \& Lawson, H. A. (2013). New Conceptual Frameworks for Student Engagement Research, Policy, and Practice. Review of Educational Research, 83(3), 432-479. https://doi.org/10.3102/0034654313480891

Leidner, D. E., \& Jarvenpaa, S. L. (1995). The Use of Information Technology to Enhance Management School Education: A Theoretical View. MIS Quarterly, 19(3), 265. https://doi.org/10.2307/249596

Liang, C. J., \& Chen, H. J. (2009). A study of the impacts of website quality on customer relationship performance. Total Quality Management and Business Excellence, 20(9), 971-988. https://doi.org/10.1080/14783360903181784

Liaw, S.-S., Huang, H.-M., \& Chen, G.-D. (2007). An activity-theoretical approach to investigate learners' factors toward e-learning systems.

Vol.2, No.1, Part 1., Jan. 2021 
Scientific Journal for Financial and Commercial Studies and Researches

Dr. Reham Shawky Ebrahim; Dr. Waleed Afify \& Dr Reda Abdelkareem

\begin{tabular}{l}
\hline \hline $\begin{array}{l}\text { Computers in Human Behavior, 23(4), } \\
\text { https://doi.org/10.1016/j.chb.2006.02.002 }\end{array}$ \\
\hline
\end{tabular}

Lin, H. F. (2007a). The impact of website quality dimensions on customer satisfaction in the B2C E-commerce context. Total Quality Management and Business Excellence, 18(4), 363-378. https://doi.org/10.1080/14783360701231302

Lin, H. F. (2007b). Measuring online learning systems success: Applying the updated DeLone and McLean model. Cyberpsychology and Behavior, 10(6), 817-820. https://doi.org/10.1089/cpb.2007.9948

Lin, H.-F. (2007). Measuring Online Learning Systems Success: Applying the Updated DeLone and McLean Model. CyberPsychology \& Behavior, 10(6), 817-820. https://doi.org/10.1089/cpb.2007.9948

Lwoga, E. (2014a). Critical success factors for adoption of web-based learning management systems in Tanzania. International Journal of Education and Development Using ICT, 10(1), 4-21.

Lwoga, Edda. (2014b). Critical success factors for adoption of web-based learning management systems in Tanzania. Journal of Education and Development Using ICT, 10(1).

Maguire, R., Egan, A., Hyland, P., \& Maguire, P. (2017). Engaging students emotionally: the role of emotional intelligence in predicting cognitive and affective engagement in higher education. Higher Education Research \& Development, 36(2), 343-357. https://doi.org/10.1080/07294360.2016.1185396

Montesdioca, G. P. Z., \& Maçada, A. C. G. (2015). Measuring user satisfaction with information security practices. Computers \& Security, 48, 267-280. https://doi.org/10.1016/j.cose.2014.10.015

Nadiri, H., Kandampully, J., \& Hussain, K. (2009). Students' perceptions of service quality in higher education. Total Quality Management \& Business Excellence, 20(5), 523-535. https://doi.org/10.1080/14783360902863713

Vol.2, No.1, Part 1., Jan. 2021 
Ortiz, M. G. R., Hoyos, J. R. C., \& López, M. G. R. (2004). The social networks of academic performance in a student context of poverty in Mexico. Social Networks, 26(2), 175-188. https://doi.org/10.1016/j.socnet.2004.01.010

Pascarella, E. T., Seifert, T. A., \& Blaich, C. (2010). How Effective are the NSSE Benchmarks in Predicting Important Educational Outcomes? Change: The Magazine of Higher Learning, 42(1), 1622. https://doi.org/10.1080/00091380903449060

Quaye, S. J. , \& Harper, S. R. (2014). Making Engagement Equitable for Students in US Higher Education Shaun R. Harper and Stephen John Quaye. In In Student Engagement in Higher Education (Routledge, pp. 17-30).

Rueda, L., Benitez, J., \& Braojos, J. (2017). From traditional education technologies to student satisfaction in Management education: A theory of the role of social media applications. Information \& Management, 54(8), 1059-1071. https://doi.org/10.1016/j.im.2017.06.002

Santos, J. (2003). E-service quality: a model of virtual service quality dimensions. Managing Service Quality: An International Journal, 13(3), 233-246. https://doi.org/10.1108/09604520310476490

Stefanovic, D., Marjanovic, U., Delić, M., Culibrk, D., \& Lalic, B. (2016). Assessing the success of e-government systems: An employee perspective. Information \& Management, 53(6), 717-726. https://doi.org/10.1016/j.im.2016.02.007

Tam, C., \& Oliveira, T. (2016). Understanding the impact of m-banking on individual performance: DeLone \&amp; McLean and TTF perspective. Computers in Human Behavior, 61, 233-244. https://doi.org/10.1016/j.chb.2016.03.016

Tam, C., \& Oliveira, T. (2017). Understanding mobile banking individual performance: The DeLone \& McLean model and the moderating

Vol.2, No.1, Part 1., Jan. 2021 
Scientific Journal for Financial and Commercial Studies and Researches

Dr. Reham Shawky Ebrahim; Dr. Waleed Afify \& Dr Reda Abdelkareem

effects of individual culture. Internet Research, 27(3), 538-562. https://doi.org/10.1108/IntR-05-2016-0117

Trowler, V. (2010). Student engagement literature review. The Higher Education Academy, 11(1), 1-15.

Tseng, S.-C., \& Tsai, C.-C. (2010). Taiwan college students' self-efficacy and motivation of learning in online peer assessment environments. The Internet and Higher Education, 13(3), 164-169. https://doi.org/10.1016/j.iheduc.2010.01.001

Wu, J.-H., \& Wang, Y.-M. (2006). Measuring KMS success: A respecification of the DeLone and McLean's model. Information \& Management, 43(6), 728-739. https://doi.org/10.1016/j.im.2006.05.002

Yilmaz, R. (2017a). Exploring the role of e-learning readiness on student satisfaction and motivation in flipped classroom. Computers in Human Behavior, 70, 251-260. https://doi.org/10.1016/j.chb.2016.12.085

Yilmaz, R. (2017b). Exploring the role of e-learning readiness on student satisfaction and motivation in flipped classroom. Computers in Human Behavior, 70, 251-260. https://doi.org/10.1016/j.chb.2016.12.085

Zhang, Z. (Victor), \& Hyland, K. (2018). Student engagement with teacher and automated feedback on L2 writing. Assessing Writing, 36, 90102. https://doi.org/10.1016/j.asw.2018.02.004 
Scientific Journal for Financial and Commercial Studies and Researches

Dr. Reham Shawky Ebrahim; Dr. Waleed Afify \& Dr Reda Abdelkareem

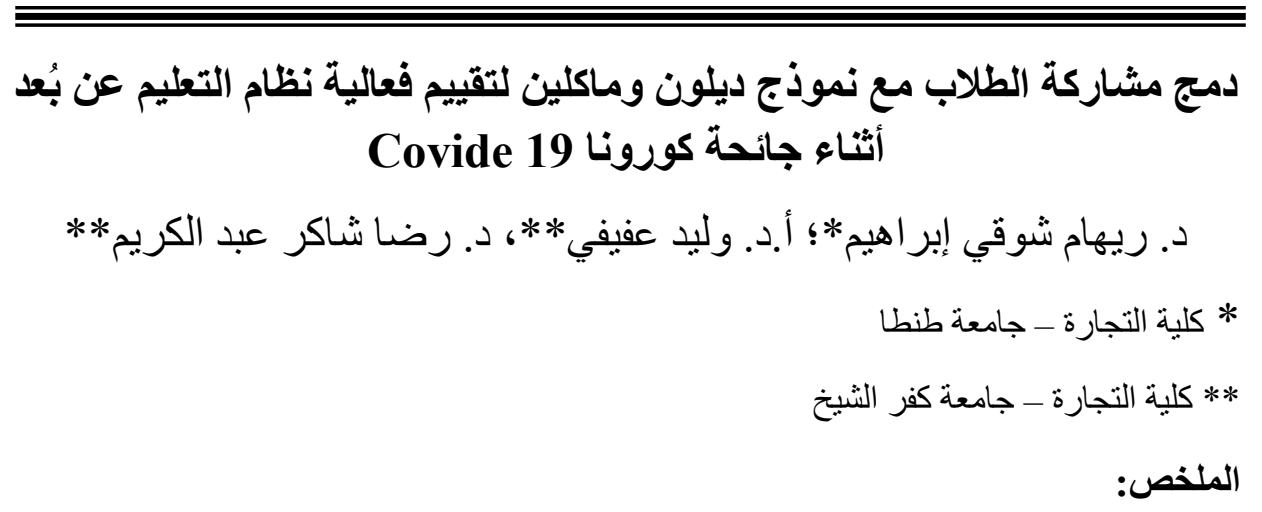

لقد خلقت أزمة كورونا (COVID-19) العديد من التحديات لمؤسسات التعليم العالي مما دفعهم

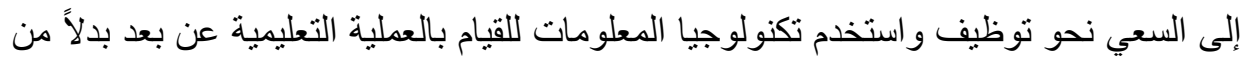

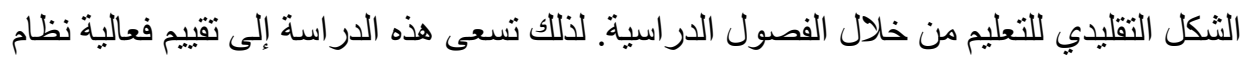

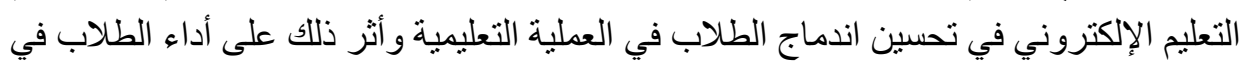

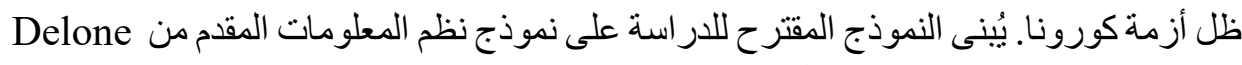
and Mclean

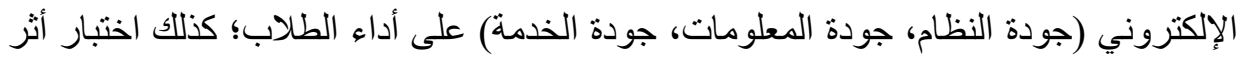

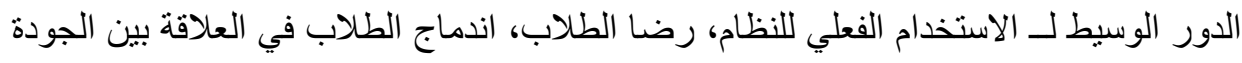

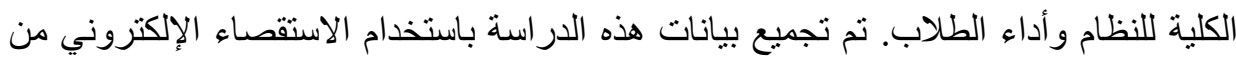

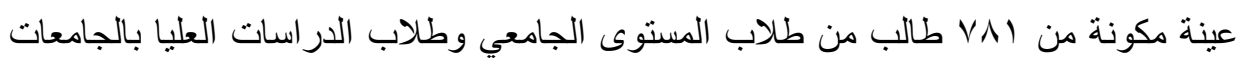

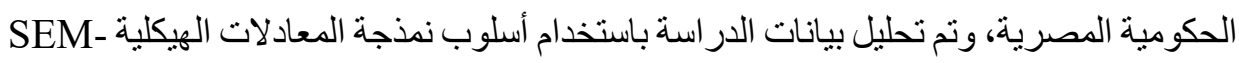

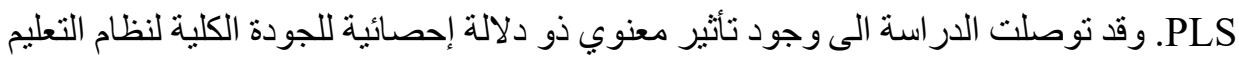

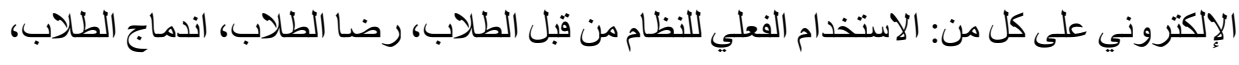

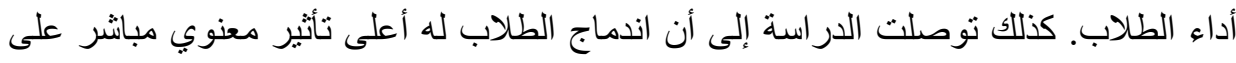

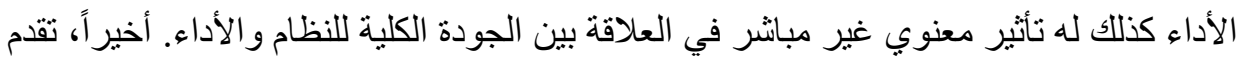

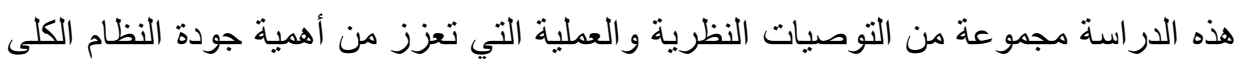
للتعليم الإلكتروني على اندماج الطلاب وفعالية نظام التعليم الإلكتروني.

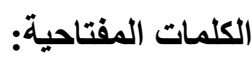
نظام التعليم الإكتروني، اندماج الطلاب، الأداء، نموذج Delone and Mclean لنظم المعلومات 